\title{
Effects of baicalein on IL-1ß-induced inflammation and apoptosis in rat articular chondrocytes
}

\author{
Yue Li ${ }^{1}$, Jinglu Wang ${ }^{1}$, Xiaopeng Song ${ }^{1}$, Hui Bai ${ }^{1}$, Tianwen Ma ${ }^{1}$, Zhiheng Zhang ${ }^{1}$, \\ Xinran Li ${ }^{1}$, Renli Jiang ${ }^{1}$, Guanying Wang ${ }^{1}$, Xiaojing Fan ${ }^{1}$, Xu Liu ${ }^{1}$ and Li Gao ${ }^{1}$ \\ ${ }^{1}$ College of Veterinary Medicine, Northeast Agricultural University, Harbin, Heilongjiang, People's Republic of China \\ Correspondence to: Li Gao, email: gaoli43450@163.com \\ Keywords: baicalein, osteoarthritis, chondrocyte, NF-KB, apoptosis, Immunology and Microbiology Section, Immune response, Im- \\ munity \\ Received: March 03, $2017 \quad$ Accepted: September 21, $2017 \quad$ Published: October 11, 2017 \\ Copyright: Li et al. This is an open-access article distributed under the terms of the Creative Commons Attribution License 3.0 (CC BY 3.0), \\ which permits unrestricted use, distribution, and reproduction in any medium, provided the original author and source are credited.
}

\section{ABSTRACT}

In osteoarthritis (OA), activated synoviocytes and articular chondrocytes produce pro-inflammatory cytokines, such as IL-1 $\beta$, that promote chondrocyte apoptosis and activate the NF-KB signaling pathway to induce catabolic factors. In this study, we examined the anti-inflammatory and anti-apoptotic effect of baicalein on IL-1 $\beta$ signaling and NF-KB-regulated gene products in rat chondrocytes. Rat chondrocytes were pretreated with $10 \mathrm{ng} / \mathrm{ml} \mathrm{IL-1} \beta$ for $24 \mathrm{~h}$ and then co-treated with $10 \mathrm{ng} /$ $\mathrm{ml} \mathrm{IL-1 \beta}$ and $50 \mu \mathrm{M}$ baicalein for $0,12,24,36$ and $48 \mathrm{~h}$. The expression levels of poly(ADP-ribose) polymerase (PARP), Bcl-2, caspase-3, matrix metalloproteinase (MMP)-9, MMP-3, cyclooxygenase (COX)-2 and SOX-9 were detected by Western blot and quantitative reverse transcription-PCR (qPCR). The effects of baicalein on the translocation and phosphorylation of the NF-kB system were studied by Western blotting and immunofluorescence. Baicalein stimulated the expression of anti-apoptotic genes and reduced the pro-apoptotic and pro-inflammatory gene products in chondrocytes. Baicalein promoted SOX-9 expression in a time-dependent manner in chondrocytes. Baicalein inhibited the NF-KB activation that was induced by IL-1 $\beta$ in a time-dependent manner in chondrocytes. Our results suggest that the anti-inflammatory and anti-apoptotic effects of baicalein are mediated through the inhibition of the translocation of phosphorylated p65 to the nucleus.

\section{INTRODUCTION}

Osteoarthritis (OA) is a common arthritic disease that gradually leads to cellular changes, structural defects and dysfunction of all the joint compartments [1]. This "whole joint disorder" is characterized by the breakdown of articular cartilage, subchondral bone sclerosis, osteophyte formation, inflammation of the synovial membrane and vascularization of the articular cartilage $[2,3]$. The causes and origins of OA have not been fully elucidated. Nevertheless, pro-inflammatory cytokines, such as IL-1 $\beta$, are produced by activated synoviocytes and articular chondrocytes and play a pivotal role in the pathogenesis of OA [4].

Baicalein is a flavonoid extracted from the dry root of Scutellaria (Huang Qin in Chinese), which is widely used in China and several other countries [5]. Baicalein is the main active constituent in a variety of flavones, amino acids and essential oils [5]. The traditional Chinese herb extract has shown antioxidant [6], anti-viral [7-11], anti-thrombotic [12, 13], anti-inflammatory [14], anticardiovascular illness $[13,15]$ and anti-tumor effects in vitro $[16,17]$ and in vivo $[18-20]$.

Currently, one study shows that nuclear factor$\kappa \mathrm{B}(\mathrm{NF}-\kappa \mathrm{B})$ activity was reduced in myeloma cell lines after baicalein treatment [21]. NF- $\mathrm{BB}$ is an inducible transcription factor that controls the expression of more than one hundred genes involved in immunity, inflammation, proliferation, and defense against apoptosis [22]. Another report shows that baicalein lowered the levels of matrix metalloproteinase (MMP)-2 and MMP-9 to inhibit tumor cell metastasis [23]. Another report reveals that Scutellaria baicalensis extracts inhibit cyclooxygenase (COX)-2 expression in vitro [19]. Apoptosis was found to correlate with cartilage destruction and matrix depletion in human osteoarthritic 
tissue specimens [24]. Chondrocytes isolated from OA cartilage, but not those isolated from normal donors, exhibited morphological evidence of apoptosis [25, 26]. These findings suggest that baicalein has the potential to inhibit apoptosis and MMPs expression in OA treatment.

In this study, we examined the anti-inflammatory and anti-apoptotic effect of baicalein on IL-1 $\beta$ signaling and NF- $\mathrm{B}$-regulated gene products in rat chondrocytes.

\section{RESULTS}

\section{Effects of baicalein on chondrocyte viability}

In the present study, we evaluated the effects of baicalein on chondrocyte viability. Proliferation and viability assays performed with the CCK- 8 kit indicated that baicalein showed no side-effects on cell viability $(P$ $>0.05)$, and the viability was not recovered in a dosedependent manner by treatment with baicalein. (Figure 1)

\section{Baicalein stimulates the expression of anti- apoptotic genes and inhibits pro-apoptotic gene products in chondrocytes}

Western blot analysis was performed with antibodies against the DNA repair enzyme PARP because cell degeneration and apoptosis are marked by enhanced caspase-mediated PARP cleavage. Treatment with baicalein inhibited IL-1 $\beta$-induced PARP cleavage, and the levels were similar to those in control cultures. (Figure 2)

Furthermore, we wanted to know whether baicalein also suppressed the IL- $1 \beta$-induced pro-apoptotic gene product and activated caspase- 3 in the same cell cultures. Therefore, chondrocytes were incubated with IL-1 $\beta$ (10 $\mathrm{ng} / \mathrm{ml}$ ) alone for $0,4,8,12$ and $24 \mathrm{~h}$ or co-incubated with $10 \mathrm{ng} / \mathrm{ml} \mathrm{IL}-1 \beta$ and $50 \mu \mathrm{M}$ baicalein for $0,12,24,36$ and $48 \mathrm{~h}$ after stimulation with $10 \mathrm{ng} / \mathrm{ml} \mathrm{IL-1 \beta}$ for $24 \mathrm{~h}$. As shown in Figure 2, co-treatment with $10 \mathrm{ng} / \mathrm{ml} \mathrm{IL-1 \beta}$ and $50 \mu \mathrm{M}$ baicalein significantly down-regulated the level of biologically active caspase- 3 in IL-1 $\beta$-stimulated cultures relative to the level in chondrocytes stimulated with IL-1 $\beta$ alone.

$\mathrm{NF}-\kappa \mathrm{B}$ is known to regulate the expression of the anti-apoptotic protein Bcl-2 [27, 28]. To evaluate whether baicalein could modulate the expression of this antiapoptotic gene product, serum-starved human articular chondrocytes were stimulated with $10 \mathrm{ng} / \mathrm{ml} \mathrm{IL-1} \beta$ alone for $0,4,8,12$ and $24 \mathrm{~h}$ or co-treated with $10 \mathrm{ng} / \mathrm{ml} \mathrm{IL-}$ $1 \beta$ and $50 \mu \mathrm{M}$ baicalein for $0,12,24,36$ and $48 \mathrm{~h}$ after stimulation with $10 \mathrm{ng} / \mathrm{ml} \mathrm{IL-1} \beta$ for $24 \mathrm{~h}$. Then, whole cell extracts were prepared and analyzed by Western blot and qPCR. As shown in Figure 2, IL-1 $\beta$ not stimulated the expression of Bcl-2. In contrast, the combined treatment of $10 \mathrm{ng} / \mathrm{ml} \mathrm{IL-1 \beta}$ and $50 \mu \mathrm{M}$ baicalein stimulated the expression of Bcl-2 in chondrocytes. Taken together, these results indicate that baicalein suppressed IL-1 $\beta$-induced apoptosis in chondrocytes.

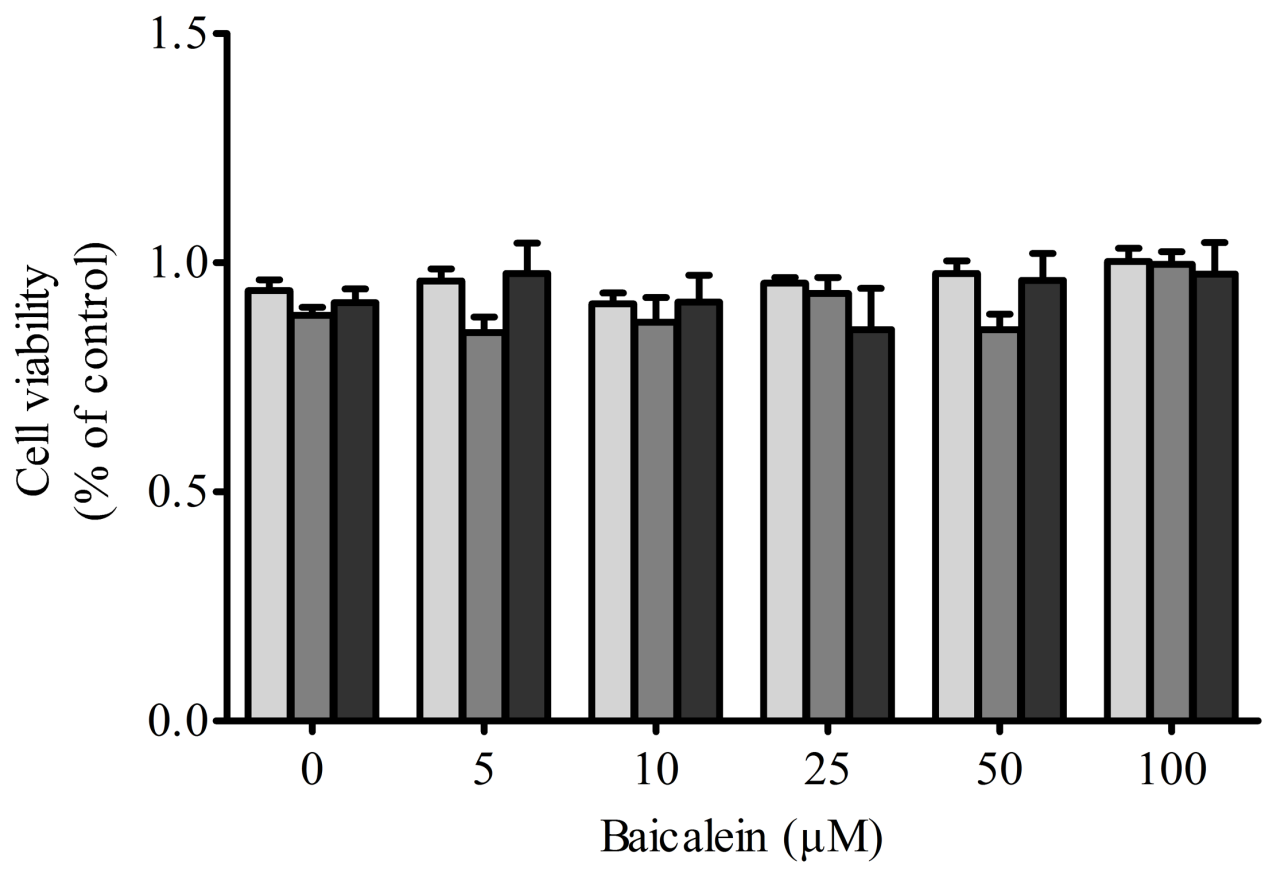

Figure 1: Effects of baicalein on the viability of chondrocytes. Rat chondrocytes were treated with $0,5,10,25,50$ and $100 \mu \mathrm{M}$ baicalein for 12, 24 and $48 \mathrm{~h}$ and evaluated by CCK-8 assay. Values are shown as the means $\pm \operatorname{SEM}(n=6) . * P<0.05 ; * * P<0.01 ; * * *$ $P<0.001$ 
Table 1: Primer sequences used in quantitative reverse transcription-PCR.

\begin{tabular}{|l|l|l|}
\hline \multirow{2}{*}{ PARP $P$} & & Primer sequences (5' to 3') \\
\hline \multirow{2}{*}{ active caspase-3 } & Forward & TGCAGAGTGTTCCAGACCAG \\
\cline { 2 - 3 } & Reverse & CACCCTCCAAGAAGAGCAAG \\
\hline \multirow{2}{*}{ Bcl-2 } & Forward & GCTGGACTGCGGTATTGAGA \\
\cline { 2 - 3 } & Reverse & TAACCGGGTGCGGTAGAGTA \\
\hline \multirow{2}{*}{$M M P-3$} & Forward & GGATGACTTCTCTCGTCGCT \\
\cline { 2 - 3 } & Reverse & GACATCTCCCTGTTGACGCT \\
\hline \multirow{2}{*}{$M M P-9$} & Forward & TTTGGCCGTCTCTTCCATCC \\
\cline { 2 - 3 } & Reverse & GCATCGATCTTCTGGACGGT \\
\hline \multirow{2}{*}{ COX-2 } & Forward & GATCCCCAGAGCGTTACTCG \\
\cline { 2 - 3 } & Reverse & GTTGTGGAAACTCACACGCC \\
\hline \multirow{2}{*}{$S O X-9$} & Forward & CAACACCTGAGCGGTTACCA \\
\cline { 2 - 3 } & Reverse & CAGCGGATGCCAGTGATAGA \\
\hline \multirow{2}{*}{ GAPDH } & Forward & GCGACGTCATCTCCAACATC \\
\cline { 2 - 3 } & Reverse & ATGCCGTAGCTGCCAGTGTA \\
\hline & Forward & GATGCCCCCATGTTTGTGAT \\
\cline { 2 - 3 } & Reverse & GGCATGGACTGTGGTCATGAG \\
\hline
\end{tabular}

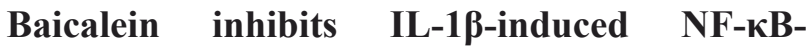 dependent pro-inflammatory gene products in chondrocytes}

We investigated whether baicalein could modulate IL-1 $\beta$-induced NF-kB-regulated gene products involved in the inflammation of chondrocytes. It has been shown previously in chondrocytes that IL-1 $\beta$ stimulation activates COX-2 [29], MMPs [30] expression. We therefore investigated whether this natural product was able to inhibit the IL-1 $\beta$-induced expression of these proteins. Serum-starved human articular chondrocytes were treated with $10 \mathrm{ng} / \mathrm{ml} \mathrm{IL-1} \beta$ for $24 \mathrm{~h}$ and then cotreated with $50 \mu \mathrm{M}$ baicalein and $10 \mathrm{ng} / \mathrm{ml} \mathrm{IL}-1 \beta$ for 0,12 , 24,36 and $48 \mathrm{~h}$, and total cellular protein and mRNA were prepared and analyzed by Western blot and qPCR. IL-1 $\beta$ induced the expression of COX-2, MMP-3 and MMP-9 in a time-dependent manner, and the combined treatment of baicalein and IL- $1 \beta$ inhibited the expression of the abovementioned proteins in chondrocytes (Figure 3).

\section{Effect of baicalein on SOX-9 in chondrocytes}

SOX-9 is a master specific transcription factor that controls the expression of chondrocyte-specific ECM protein genes and plays a pivotal role in chondrocyte differentiation [31]. To test the hypothesis whether the phytochemical is able to activate the transcription factor SOX-9 in chondrocytes, monolayer cultures of chondrocytes were stimulated with $50 \mu \mathrm{M}$ baicalein and $10 \mathrm{ng} / \mathrm{ml} \mathrm{IL-1} \beta$ for $0,12,24,36$ and $48 \mathrm{~h}$ after incubated with $10 \mathrm{ng} / \mathrm{ml} \mathrm{IL-1 \beta}$ alone for $24 \mathrm{~h}$, and cell lysates were analyzed by Western blot and qPCR. The results demonstrated that baicalein-induced SOX-9 increasing is stronger than the IL-1 $\beta$-induced SOX-9 decreasing (Figure 4).

\section{Baicalein inhibits NF- $\kappa \mathrm{B}$ activation induced by IL-1 $\beta$ in a time-dependent manner in chondrocytes}

\section{Effect of baicalein on IL-1ß-induced phosphorylation of NF- $\kappa B$ in the cytoplasm}

To test the effect of baicalein on IL- $1 \beta$ activation of NF- $\mathrm{kB}$, serum-starved chondrocytes were treated with $10 \mathrm{ng} / \mathrm{ml} \mathrm{IL}-1 \beta$ for $0,10,15,30$ and 60 min alone, and other cultures were treated with $10 \mathrm{ng} / \mathrm{ml} \mathrm{IL-1} \beta$ for the same time periods alone and together with $50 \mu \mathrm{M}$ baicalein for $4 \mathrm{~h}$. Cytoplasmic extracts were investigated for the expression of pan/ phospho p65 by Western blot analysis. p65 phosphorylation is a known prerequisite for $\mathrm{NF}-\kappa \mathrm{B}$ transcriptional functions, and this phosphorylation is mediated by IKK [32]. As shown in Figure 5, IL-1 $\beta$ induced phosphorylation of the p65 cytoplasmic pool in a time-dependent manner. This phosphorylation could be observed as early as $10 \mathrm{~min}$ and increased up to $50 \mathrm{~min}$. In chondrocytes that were treated with baicalein, the IL$1 \beta$-induced activation of cytoplasmic p 65 was completely blocked.

\section{Effects of baicalein on IL-1 $\beta$-induced phosphorylation of $\mathrm{p} 65$ in the nucleus}

Translocation of NF- $\mathrm{\kappa B}$ to the nucleus is necessary for the regulation of gene expression. The translocation of activated NF- $\mathrm{KB}$ is preceded by phosphorylation of the p65 subunit of NF- $\mathrm{kB}$ [33]. Therefore, to test this, protein extracts of serum-starved chondrocyte nuclear extracts were probed for the pan and phosphorylated p $65 \mathrm{NF}-\mathrm{\kappa B}-$ 
subunit after stimulation of chondrocytes with $10 \mathrm{ng} / \mathrm{ml}$ IL-1 $\beta$ for $0,10,15,30$ and $60 \mathrm{~min}$. To show the effect of baicalein on p 65 phosphorylation, other cultures were first treated with $10 \mathrm{ng} / \mathrm{ml} \mathrm{IL}-1 \beta$ alone for the same time periods, and then every time course was co-treated with $50 \mu \mathrm{M}$ baicalein for $4 \mathrm{~h}$. Chondrocytes treated with 10 $\mathrm{ng} / \mathrm{ml}$ IL-1 $\beta$ at different time points revealed a visible increase in pan p65 subunit and phospho p65 in a timedependent manner in the nuclear extracts (Figure 6). The co-treatment of chondrocytes with baicalein and IL-1 $\beta$ abolished the pan p65 subunit and the IL-1 $\beta$-dependent phosphorylation of p65 in a time-dependent manner in the nucleus. These results clearly show that baicalein inhibits the IL-1 $\beta$-induced translocation of p65 to the nucleus. The synthesis of the Lamin B1 protein remained unaffected.

\section{Baicalein blocks IL-1 $\beta$-induced nuclear translocation of NF-кB visualized by immunofluorescence microscopy}

Immunofluorescence microscopy was employed to reveal translocation of the phosphorylated p65 subunit of NF- $\kappa \mathrm{B}$ from the chondrocyte cytoplasm to the nucleus in response to NF- $\kappa \mathrm{B}$ activation by IL-1 $\beta$. Unstimulated chondrocytes or those stimulated with 10 $\mathrm{ng} / \mathrm{ml} \mathrm{IL}-1 \beta$ alone for $30 \mathrm{~min}$ or co-treated with $10 \mathrm{ng} /$ $\mathrm{ml} \mathrm{IL}-1 \beta$ for $30 \mathrm{~min}$ and then $50 \mu \mathrm{M}$ baicalein for $2 \mathrm{~h}$

\begin{tabular}{|c|c|c|c|c|c|c|c|c|c|c|c|}
\hline & & & & & & \multicolumn{6}{|c|}{ IL-1 $\beta+$ Baicalein } \\
\hline & \multicolumn{5}{|c|}{ IL-1 $\beta$} & 0 & 12 & 24 & 36 & 48 & $\mathrm{t}(\mathrm{h})$ \\
\hline & 0 & 4 & 8 & 12 & 24 & 24 & 36 & 48 & 60 & 72 & $\mathrm{t}(\mathrm{h})$ \\
\hline PARP & - & $\square$ & - & $\overline{ }$ & 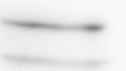 & - & 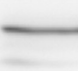 & $\longrightarrow$ & 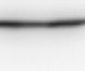 & $\longrightarrow$ & \\
\hline
\end{tabular}

active caspase- 3

Bcl-2
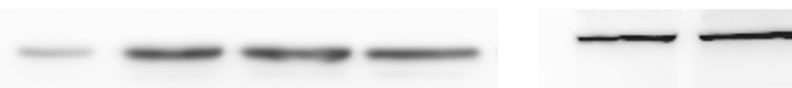

GAPDH
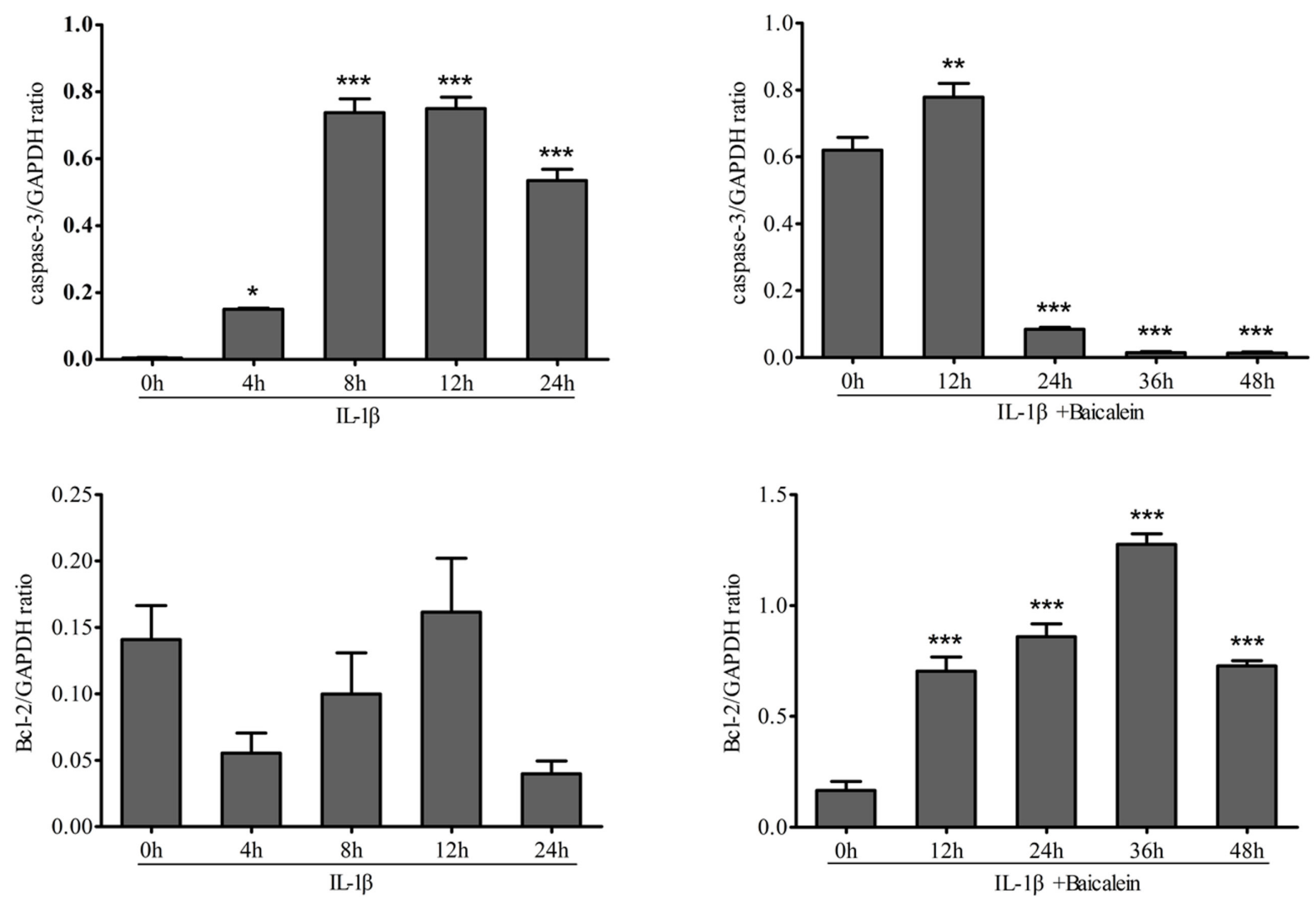


\section{B}
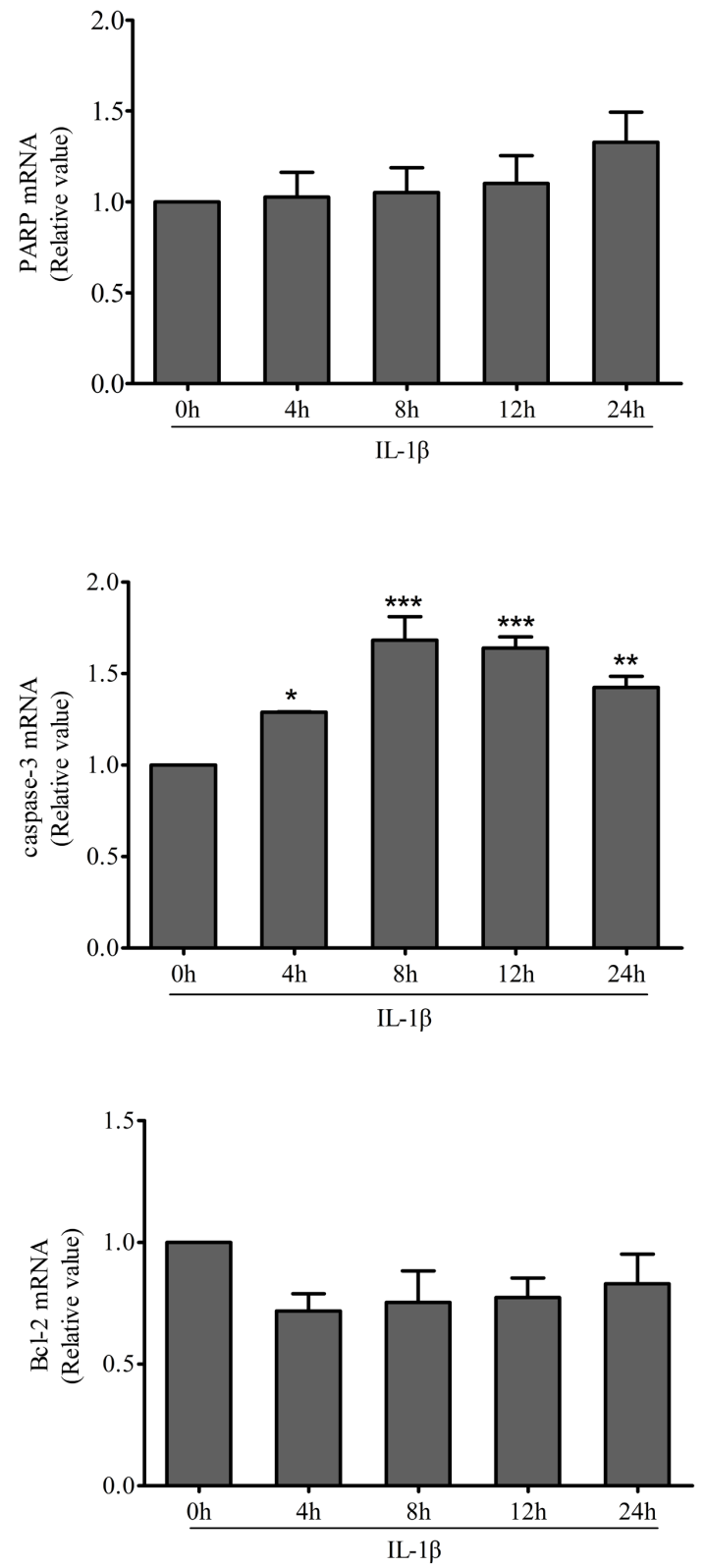
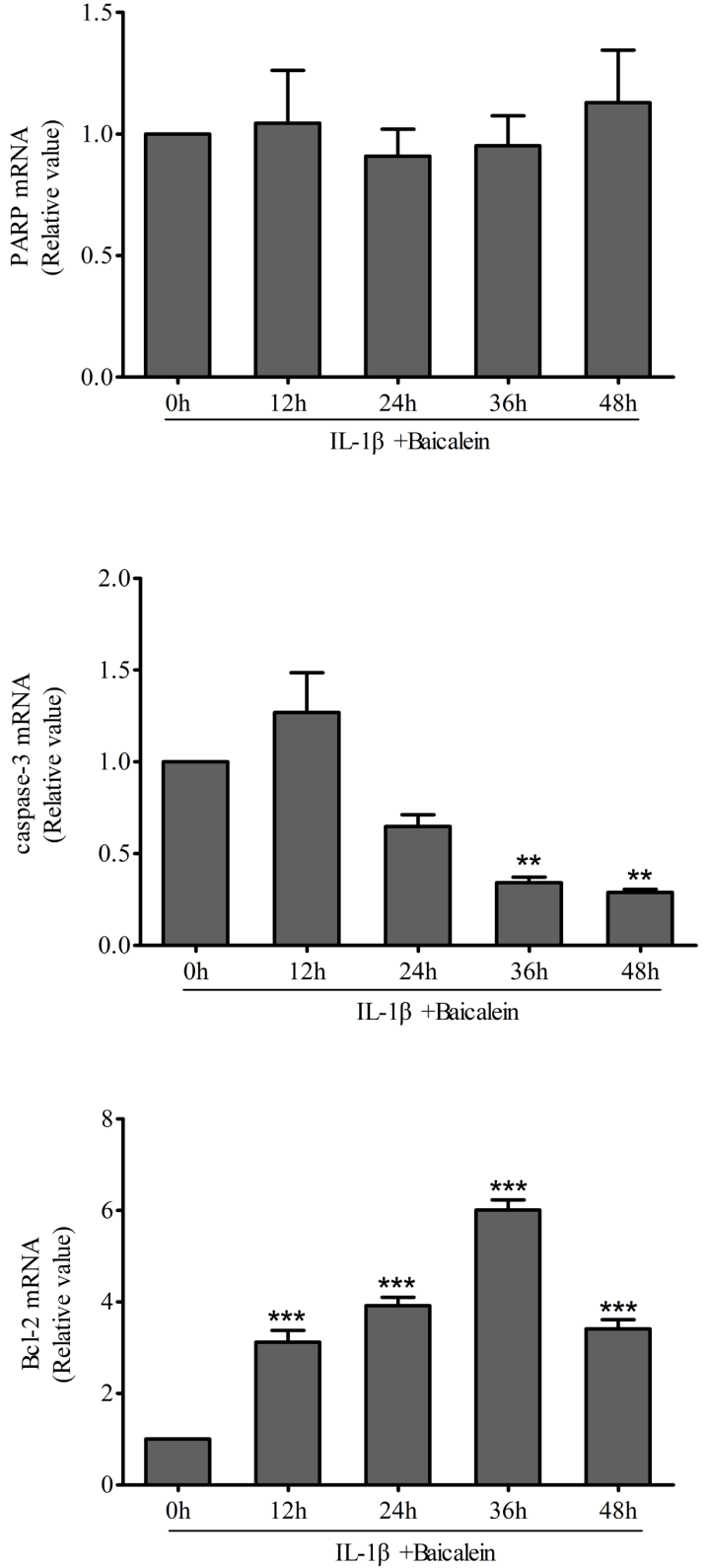

Figure 2: Baicalein stimulates the expression of anti-apoptotic proteins and inhibits pro-apoptotic gene products in chondrocytes. A., B. Protein expression A. of PARP, active caspase-3 and Bcl-2; and their gene expression B. in chondrocytes, as estimated by Western blot and qPCR. Cultures were treated with $10 \mathrm{ng} / \mathrm{ml} \mathrm{IL}-1 \beta$ for $0,4,8,12$ and $24 \mathrm{~h}$ or co-treated with $50 \mu \mathrm{M}$ baicalein and $10 \mathrm{ng} / \mathrm{ml} \mathrm{IL}-1 \beta$ for $0,12,24,36$ and $48 \mathrm{~h}$ after exposure to $10 \mathrm{ng} / \mathrm{ml} \mathrm{IL-1} \beta$ alone for $24 \mathrm{~h}$. Values are shown as the means $\pm \operatorname{SEM}(n=$ 5). * $P<0.05$;** $P<0.01$; *** $P<0.001$.

before immunolabeling with anti-phospho p65 antibody were compared. The control chondrocytes showed only cytoplasmic labeling of phospho p65. IL-1 $\beta$ stimulated cells revealed clear and intense cytoplasmic and nuclear staining for phospho p65. Co-treatment of chondrocytes with IL-1 $\beta$ and baicalein resulted in inhibition of nuclear translocation of activated phospho p65, decreased cytoplasmic staining for this protein and decreased activation of NF- $\mathrm{KB}$ (Figure 7). These immunomorphological findings were consistent with the 

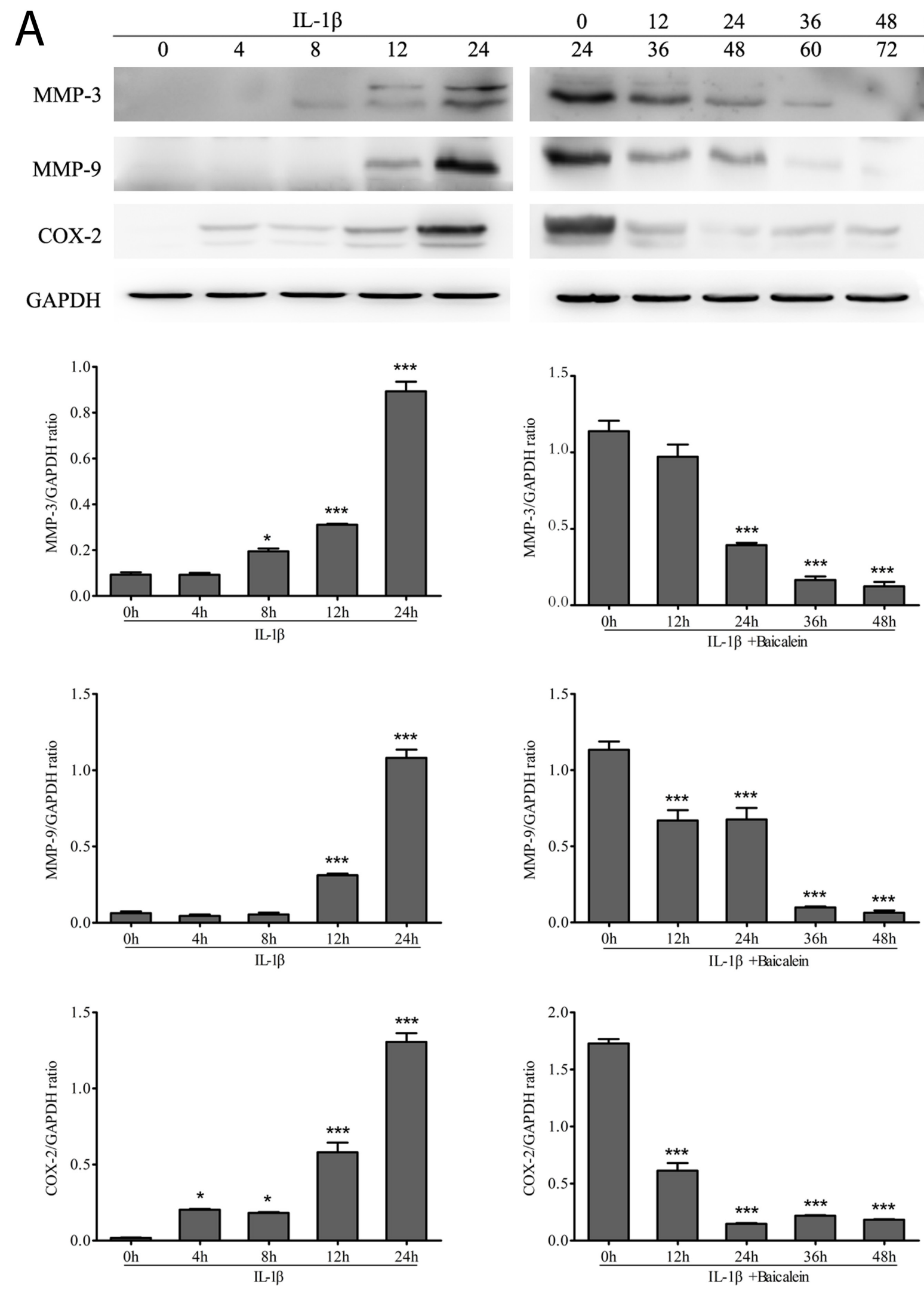


\section{B}
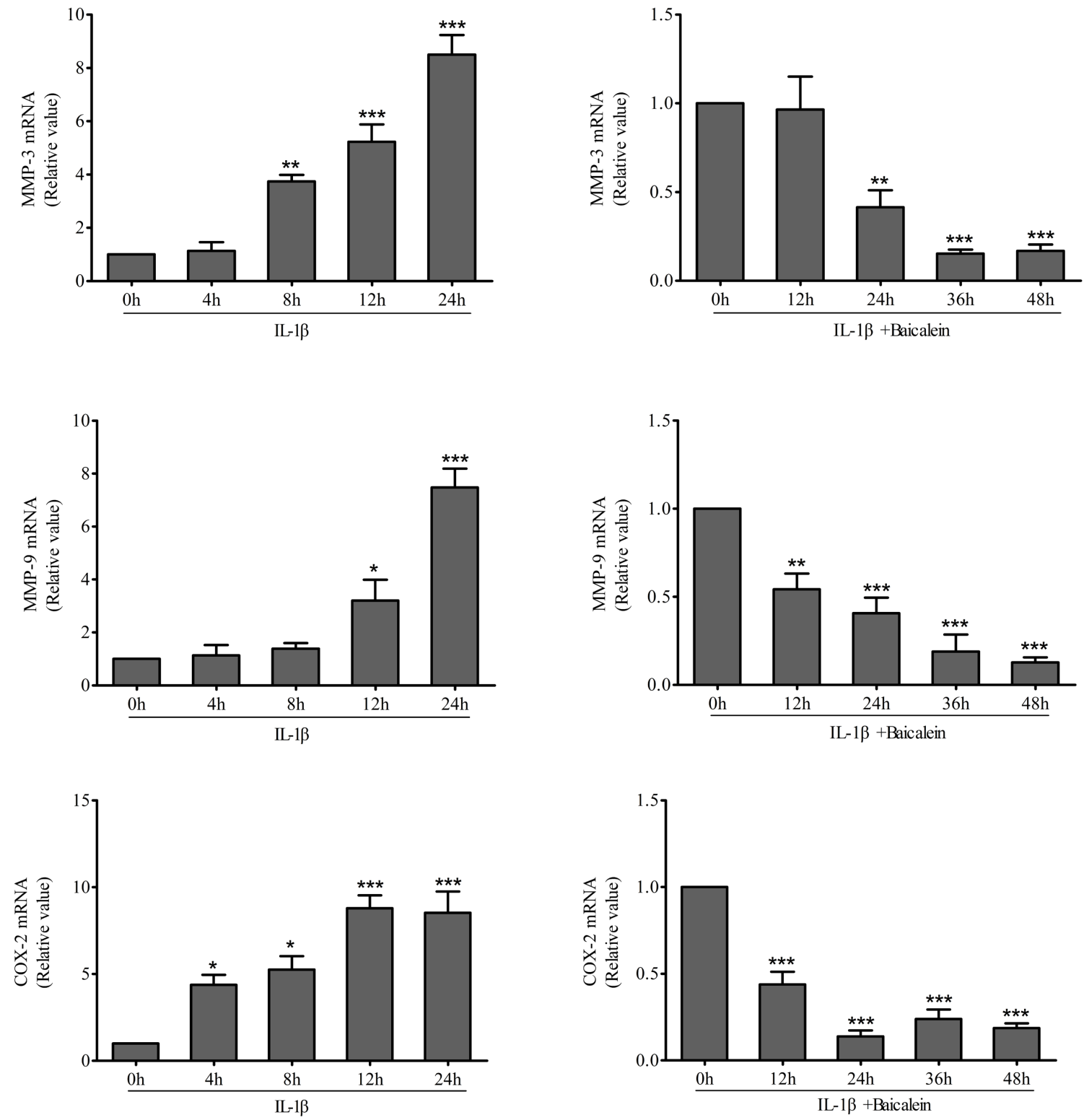

Figure 3: Up-regulation of pro-inflammatory enzymes by IL-1ß in chondrocytes is inhibited by baicalein. A., B. Protein expression A. of MMP-3, MMP-9 and COX-2; and their gene expression B. in chondrocytes, as estimated by Western blot and qPCR. Cells were treated as described in Figure 2. Values are shown as the means $\pm \operatorname{SEM}(n=5) . * P<0.05 ; * * P<0.01 ; * * * P<0.001$.

NF-kB inhibition observed by Western blot.

\section{DISCUSSION}

This study led to the following findings: (1) baicalein shows no side-effects on chondrocyte viability, and viability was not recovered in a dose-dependent manner by treatment with baicalein; (2) IL-1 $\beta$-stimulated cells treated with baicalein inhibit the activation of PARP cleavage; (3) baicalein exerts anti-inflammatory and anti-apoptotic effects; (4) baicalein suppresses the IL-1 $\beta$ induced down-regulation of the cartilage-specific master transcription factor SOX-9; (5) baicalein antagonizes the IL-1 $\beta$-induced phosphorylation and nuclear translocation 
of the p65 NF-kB subunit.

Baicalein (5, 6, 7-trihydroxyflavone), the principal component of the roots of Scutellaria baicalensis Georgi extract, is known as Huang Qin in Chinese traditional medicine [34]. Due to its excellent biological action, baicalein has been the focus of pharmaceutical, cosmetic, and food industry studies. It has been reported that the herbal extract shows anti-inflammatory effects and improvements of mitochondrial dysfunction [35]. In addition, pre-incubation of baicalein caused an increase of Bcl-2 [36] and blocked the activation of caspases [37]. The expression of caspase-3, the cellular death marker, and Bcl-2, the anti-apoptotic member of the Bcl-2 family, was shown to be suppressed by NF- $\kappa \mathrm{B}$ [38-40]. In the present study, we found that baicalein inhibited the expression of caspase- 3 in IL-1 $\beta$-stimulated chondrocytes and promoted the expression of $\mathrm{Bcl}-2$ in the same condition. It is well known that poly (ADP-ribose) polymerase (PARP) is a nuclear enzyme that can be activated in cells experiencing stress and/or DNA damage and is cleaved by the caspase family in vitro. We also found that baicalein antagonized the cleavage of PARP in the chondrocytes incubated with IL-1 $\beta$.

The pro-inflammatory mediators IL-1 $\beta$ and tumor necrosis factor- $\alpha$ (TNF- $\alpha$ ), which are produced by synovitis, activate chondrocytes and cause phenotypic shifts, apoptosis and aberrant expression of inflammationrelated genes, including COX-2 and MMPs [41-43], which play key roles in the initiation and perpetuation of osteoarthritic cartilage destruction [44, 45]. Seven matrix metalloproteinases have been found during a variety of circumstances in articular cartilage, including MMP-1,

A

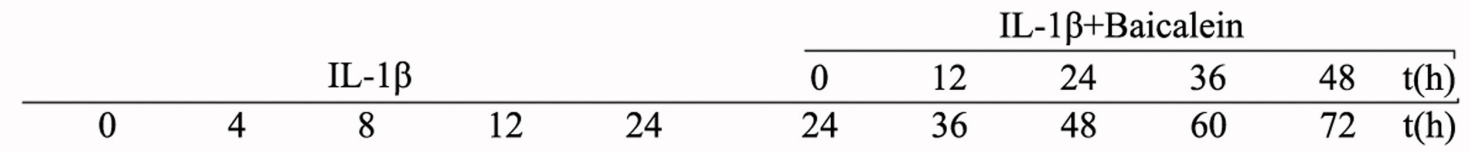

SOX-9
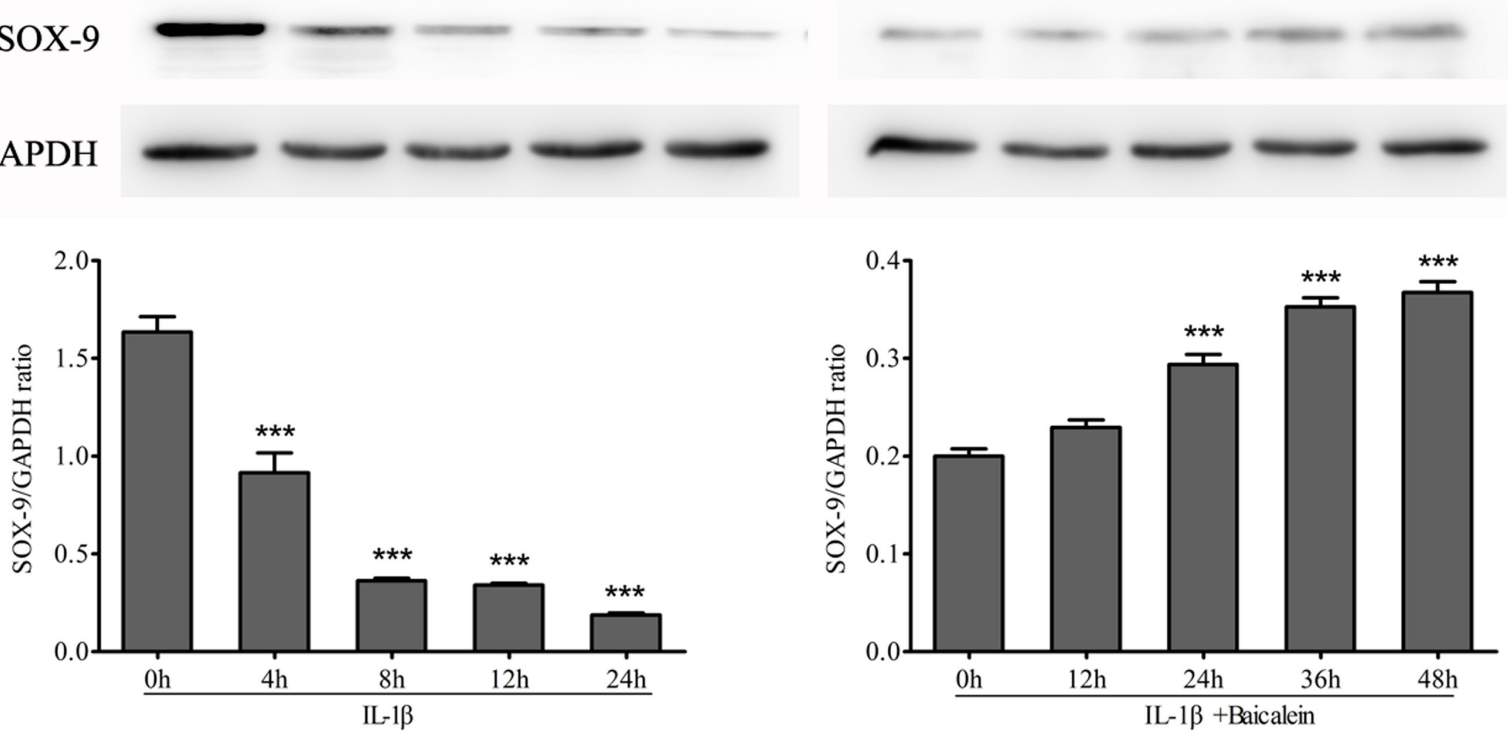

B
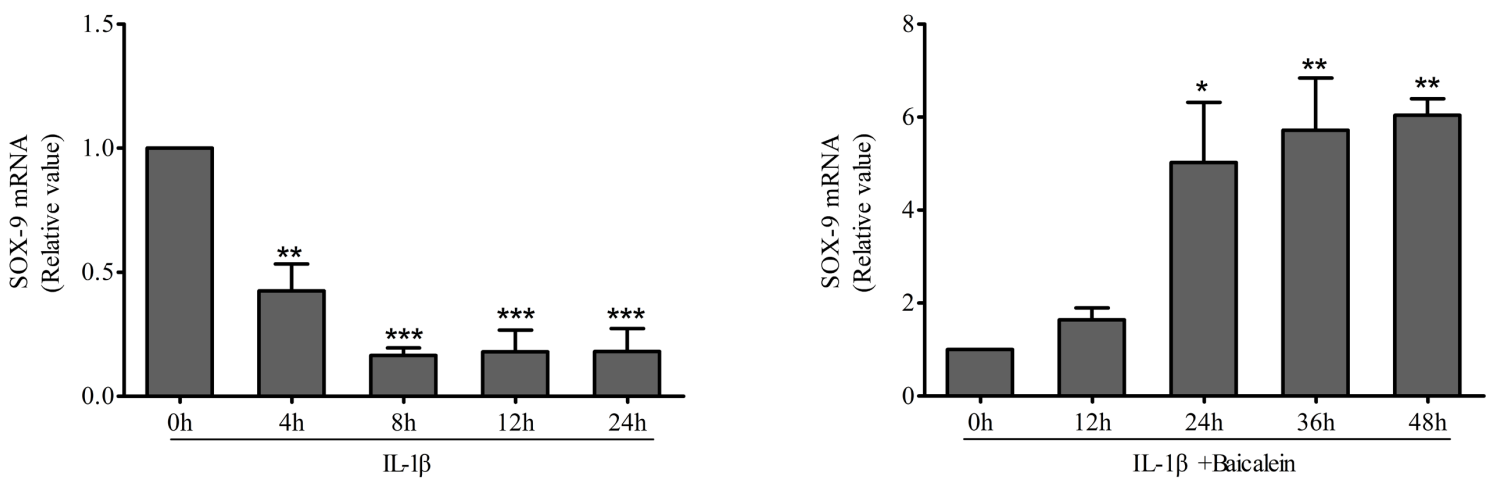

Figure 4: Effects of baicalein on IL-1 $\beta$-induced inhibition of SOX-9 production in chondrocytes. A., B. Protein expression A. of SOX-9 and their gene expression B. in chondrocytes, as estimated by Western blot and qPCR. Cells were treated as described in Figure 2. Values are shown as the means $\pm \operatorname{SEM}(n=5)$. ${ }^{*} P<0.05 ; * * P<0.01$; *** $P<0.001$. 
MMP-2, MMP-3, MMP-8, MMP-9, MMP-13 and MMP14 [46]. The expression of MMP-3 and MMP-9 in cartilage is characteristic of the pathologic circumstances of OA. MMP-3 degrades a wide array of extracellular molecules, such as collagen type II and various proteoglycans, and up-regulates the expression of other MMPs [47]. MMP9 reveals extremely strong activity in the disintegration of all collagen types but also native collagens, like type IV and type XI [45]. In this study, IL-1 $\beta$ stimulated the time-dependent up-regulation of MMPs, while baicalein showed an antagonistic effect. COX-2 is an important mediator of pain and inflammation in osteoarthritic joints [48]. COX-2, but not COX-1, production is stimulated by IL- $1 \beta$ and TNF- $\alpha[29,49]$. COX-2 activity leads to PGE2 and thromboxane production [50-52]. PGE2 exerts some additional catabolic effects on chondrocytes, such as decreased proliferation of chondrocytes and inhibition of proteoglycan synthesis [47]. As a result, baicalein suppressed the synthesis of COX-2 in IL- $1 \beta$-stimulated chondrocytes, but the expression level of COX-2 remained higher than that in un-stimulated chondrocytes. We propose that the anti-inflammatory action and antiapoptotic effects of baicalein are due to the activation of $\mathrm{NF}-\kappa \mathrm{B}$ signaling because the activation of canonical NF$\kappa \mathrm{B}$ signaling is required for the expression of MMPs and COX-2 [53].
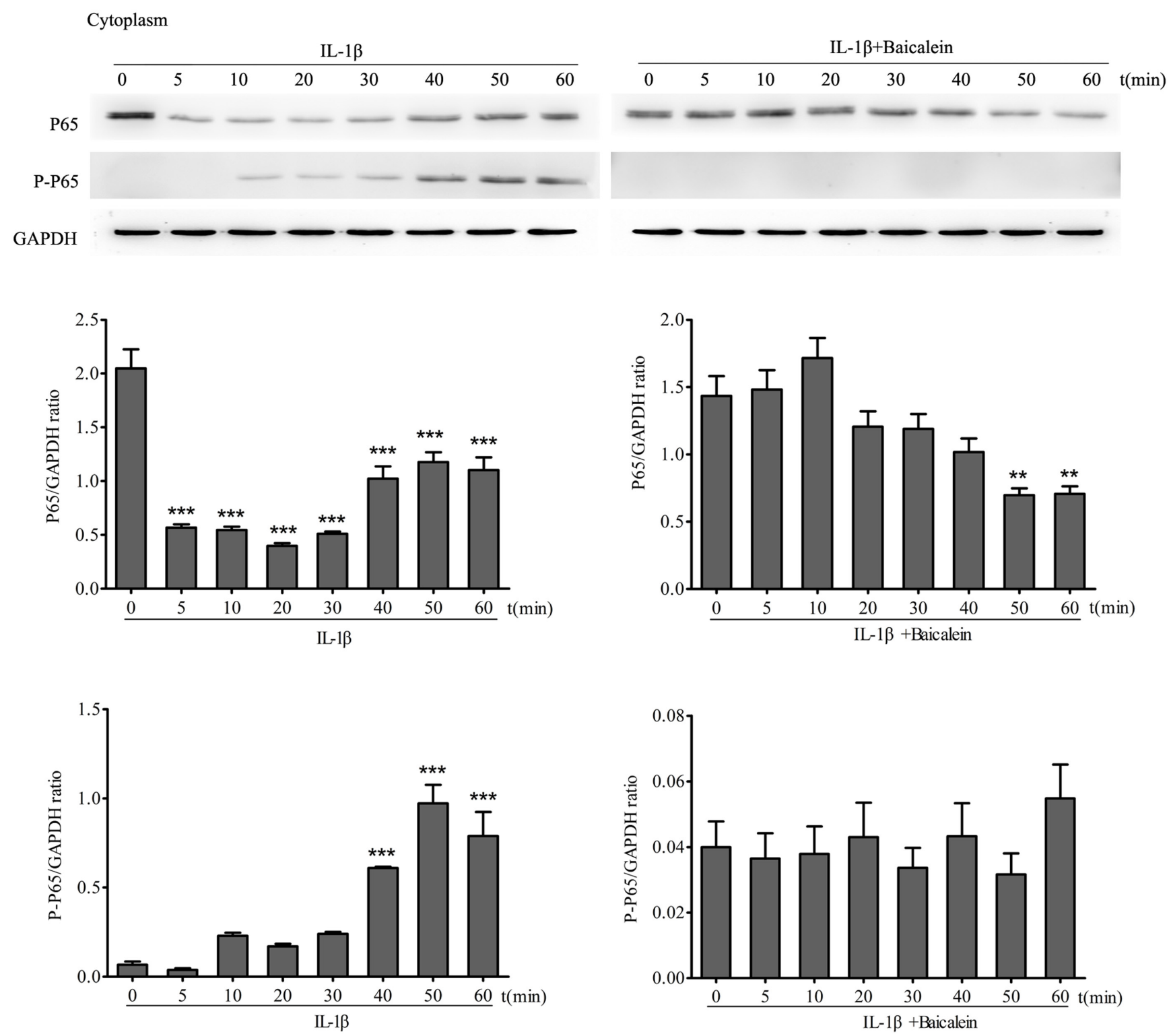

Figure 5: Baicalein inhibits IL-1 $\beta$-induced phosphorylation and translocation of p65 in cytoplasmic extracts of chondrocytes. Western blot analysis with IL- $1 \beta$-treated cytoplasmic extract. Serum-starved chondrocytes $\left(0.1 \times 10^{6}\right.$ cells $\left./ \mathrm{ml}\right)$ were treated with $10 \mathrm{ng} / \mathrm{ml} \mathrm{IL}-1 \beta$ for $0,5,10,20,30,40,50$ and $60 \mathrm{~min}$. Other cultures were initially treated with $10 \mathrm{ng} / \mathrm{ml} \mathrm{IL}-1 \beta$ for identical time periods and then co-treated with $50 \mu \mathrm{M}$ baicalein for $4 \mathrm{~h}$. Values are shown as the means $\pm \operatorname{SEM}(n=5){ }^{*} P<0.05$;** $P<0.01$; *** $P<$ 0.001 . 


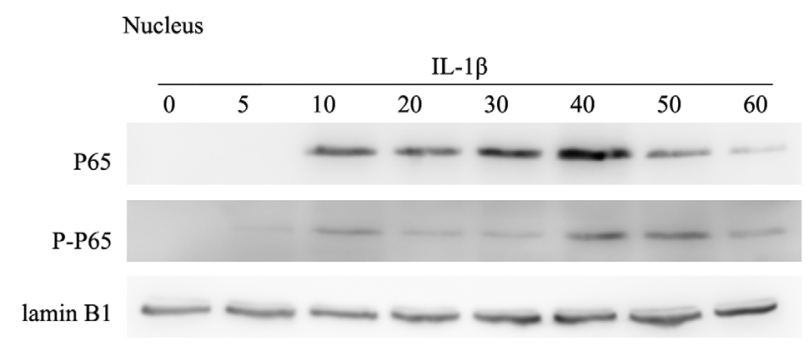

\begin{tabular}{llllllll}
\multicolumn{8}{c}{ IL-1 $\beta+$ Baicalein } \\
\cline { 1 - 5 } & 5 & 10 & 20 & 30 & 40 & 50 & 60
\end{tabular}
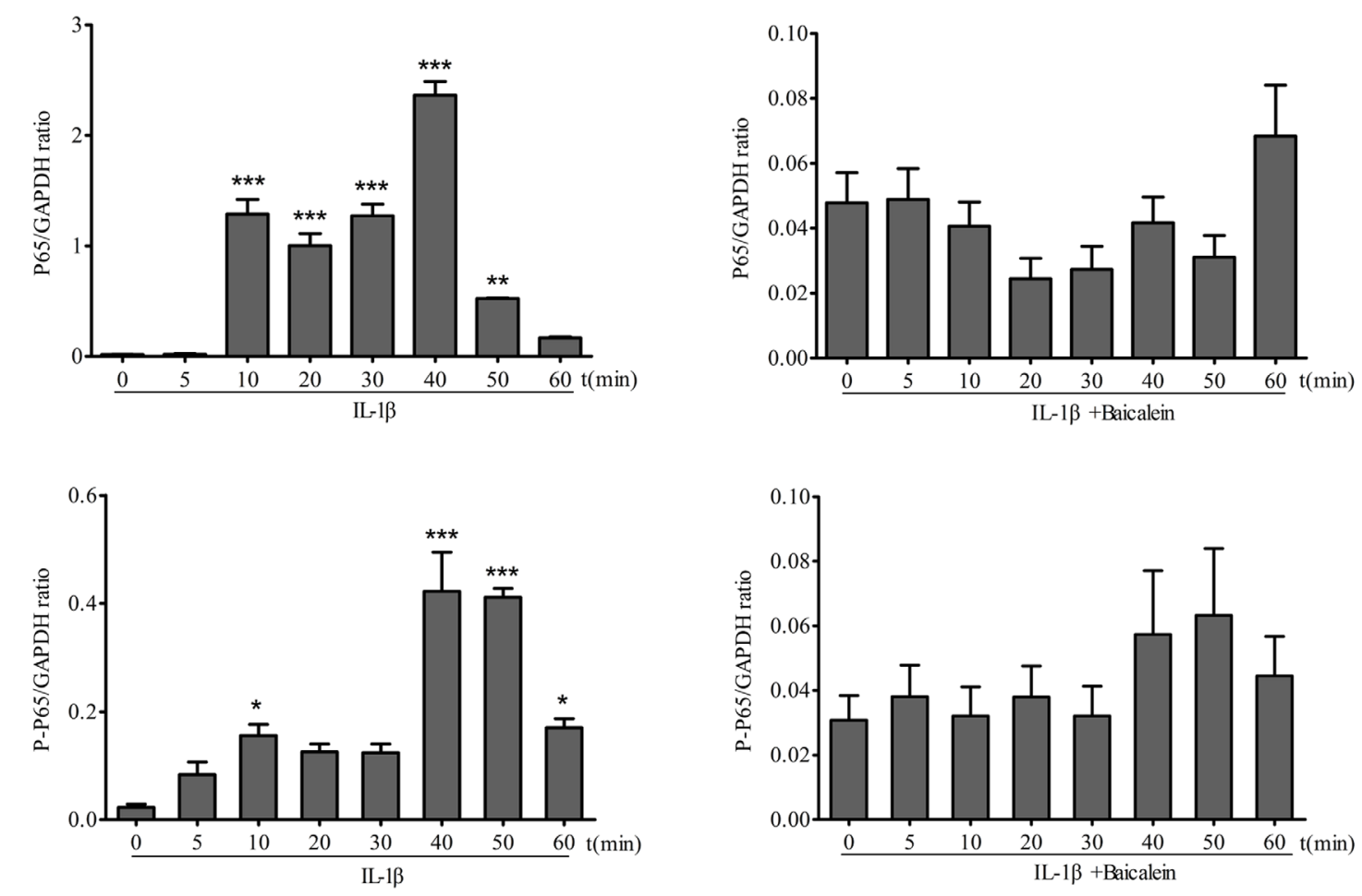

Figure 6: Baicalein inhibits IL-1 $\beta$-induced phosphorylation and translocation of p65 in nuclear extracts of chondrocytes. Western blot analysis with IL-1 $\beta$-treated nuclear extract. Cells were treated as described in Figure 5. Values are shown as the means \pm SEM $(n=5) . * P<0.05$;** $P<0.01$; *** $P<0.001$.
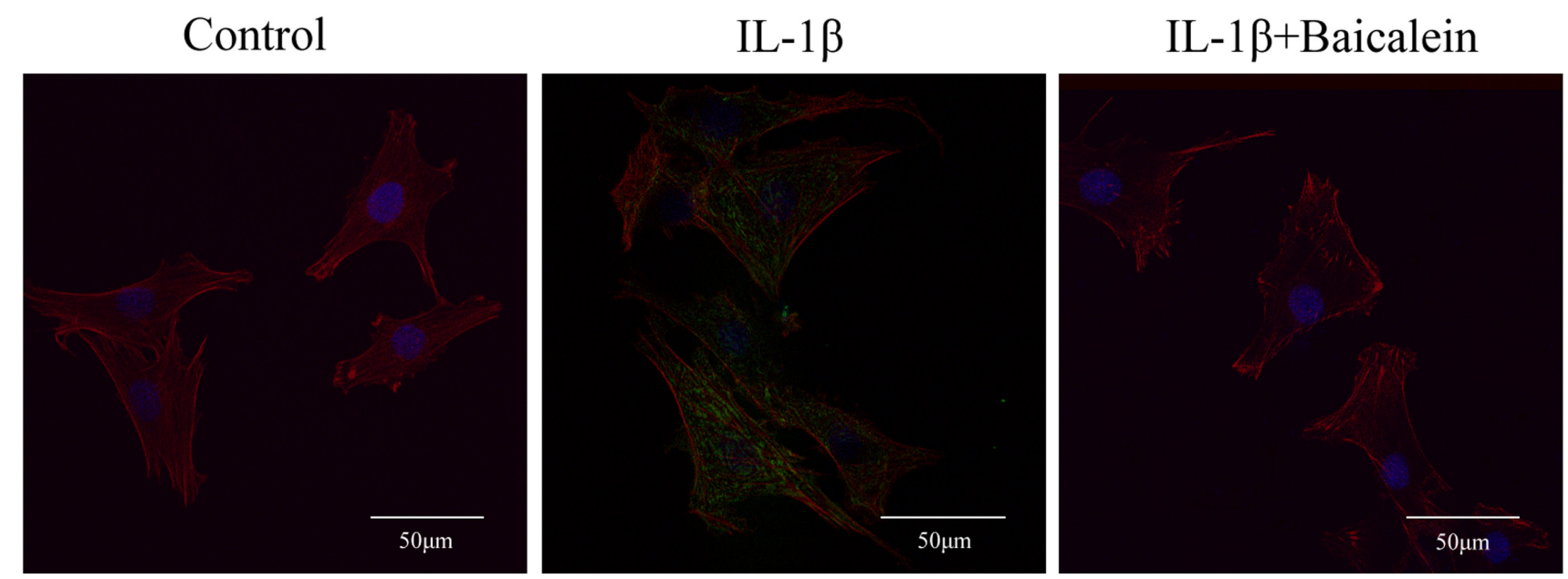

Figure 7: Baicalein inhibits IL-1 $\beta$-induced nuclear translocation of phospho $\mathrm{p} 65$ as revealed by immunofluorescence microscopy. Chondrocyte cultures either served as controls or were treated with IL- $1 \beta$ alone for $30 \mathrm{~min}$ or co-treated with $10 \mathrm{ng} / \mathrm{ml} \mathrm{IL-}$ $1 \beta$ and $50 \mu \mathrm{M}$ baicalein for $2 \mathrm{~h}$ after treatment with IL-1 $1 \beta$ alone for $30 \mathrm{~min}$. Confocal immunofluorescent analysis of chondrocytes using Phospho-NF-kB p65 Antibody (green), Phalloidin (red) and DAPI (blue). 
Activation of $\mathrm{NF}-\kappa \mathrm{B}$ is crucial to the pathogenesis of arthritis, and targeting NF- $\mathrm{BB}$ both alleviates inflammation and inhibits hyperplasia in arthritis [54]. Thus, NF- $\kappa$ B represents an essential target for the treatment of $\mathrm{OA}$. In the inactive state, transcription factors of the NF- $\mathrm{B}$ family are held in check by inhibitors called inhibitor of $\kappa \mathrm{B}(\mathrm{I} \kappa \mathrm{Bs})$ in the cytoplasm [55]. Upon stimulation by different stressors, the phosphorylated p65 subunit of NF- $\kappa \mathrm{B}$ translocates to the nucleus and binds DNA [56]. In addition, reduced NF- $\kappa \mathrm{B}$ activity was observed in myeloma cell lines after baicalein treatment [21]. In the present study, the phosphorylation of p65 in nuclear extracts of chondrocytes cultured with IL-1 $\beta$ was significantly increased, as demonstrated by Western blot analysis, implying that phospho p65 had translocated to the nucleus from the cytoplasm, thus activating NF- $\kappa$ B. The same phenomenon could also be demonstrated by immunofluorescence microscopy. Baicalein inhibited the translocation of phosphorylated p65 to the nucleus, which was confirmed by Western blot analysis and immunofluorescence microscopy.

SOX-9 is essential for chondrogenesis and chondrocyte differentiation [57-59]. It is unclear whether the differentiation state of chondrocytes could cause OA [60]. However, a recent study showed that the loss of phenotypic stability of articular chondrocytes could indeed constitute an initiating event [61]. SOX-9 expression is essential for the survival of chondrocytes, as it can progress chondrocytes to hypertrophy $[58,59,62]$. SOX9 has been shown to both activate and inhibit the expression of type X collagen in hypertrophic chondrocytes [63, 64]. In this study, we observed that baicalein promoted the expression of SOX-9 that was reduced in chondrocytes after IL-1 $\beta$ treatment, though the quantity was less than in normal chondrocytes. Therefore, more studies are needed to obtain a better understanding of the in vivo effects of baicalein on cartilage damage in OA.

In conclusion, these results suggest that the antiinflammatory and anti-apoptotic effects of baicalein are mediated through inhibition of the translocation of phosphorylated p65 to the nucleus. While a large variety of intracellular signaling pathways are involved in OA, it is unclear whether there are additional molecular targets of baicalein. Thus, further in vitro and in vivo studies will be required to explore the potential effects of baicalein for the prevention and treatment of OA.

\section{MATERIALS AND METHODS}

\section{Antibodies}

Monoclonal anti-SOX-9 and anti-MMP-9 (EP1255Y) were obtained from Abcam (Cambridge Science Park, UK). Antibodies raised against PARP
(46D11), Bcl-2 (50E3), cleaved caspase-3 (8G10), MMP3 (D7F5B), COX-2 (D5H5), NF-кB p65 (D14E12), phospho-NF-кB p65 (Ser536, 93H1) and Anti-rabbit IgG $(\mathrm{H}+\mathrm{L}), \mathrm{F}\left(\mathrm{ab}{ }^{\prime}\right) 2$ Fragment (Alexa Fluor ${ }^{\circledR} 488$ Conjugate) were obtained from Cell Signaling Technology (Beverly, MA, USA). Antibodies to GAPDH, sheep anti-mouse and sheep anti-rabbit secondary antibodies were obtained from ZSGB-BIO (Beijing, China). All antibodies were used at concentrations and dilutions recommended by the manufacturer (dilutions ranged from 1:100 for immunomorphological experiments to $1: 10,00$ for Western blot analysis).

\section{Growth medium and chemicals}

Growth medium (DMEM/F-12 (50/50) containing $10 \% \mathrm{FBS}, 50 \mu \mathrm{g} / \mathrm{ml}$ streptomycin, $50 \mathrm{IU} / \mathrm{ml}$ penicillin, essential amino acids and L-glutamine) was obtained from Gibco (Life Technologies, NY, USA). Baicalein was purchased from Sigma-Aldrich (St. Louis, MO, USA). Baicalein was prepared as a $100 \mu \mathrm{M}$ solution in dimethylsulfoxide (DMSO) and then further diluted in cell culture medium. IL-1 $\beta$ was obtained from PeproTech (NJ, USA). Cell lysis buffer for Western blot was ordered from Beyotime (Jiangsu, China). Cell counting kit-8 (CCK-8) was acquired from Dojindo (Kyushu, Japan). RNAiso Plus, PrimeScript RT reagent kit and SYBR Premix Ex Taq was obtained from Takara (Beijing, China). Alexa Fluor $^{\circledR} 555$ Phalloidin and DAPI were purchased from Cell Signaling Technology (Beverly, MA, USA).

\section{Chondrocyte isolation and culture}

Primary cultures of rat chondrocytes were isolated from articular cartilage as previously described [65]. Cartilage slices were digested primarily with $0.25 \%$ (v/v) trypsin for $30 \mathrm{~min}$ at $37^{\circ} \mathrm{C}$ and subsequently with $0.2 \%(\mathrm{w} / \mathrm{v})$ collagenase Type II for $4-8$ hours at $37^{\circ} \mathrm{C}$ in a shaker. Primary chondrocytes were cultured at a density of $2 \times 10^{6}$ cells $/ \mathrm{ml}$ in growth medium at $37^{\circ} \mathrm{C}$ with $5 \%$ $\mathrm{CO}_{2}$. When the cells reached $80 \%$ confluence, they were passaged, and the chondrocytes of passage 2 were used for subsequent experiments.

\section{Cell viability assay}

Cell viability was measured by colorimetric CCK-8 assay. Briefly, 5,000 chondrocytes per well were cultured for $24 \mathrm{~h}$ in a 96-well-plate and then washed three times with serum-starved medium and incubated for $12 \mathrm{~h}$ with serum-starved medium (0.5\% FBS). Serum-starved human articular chondrocytes were treated with $0 \mu \mathrm{M}, 5 \mu \mathrm{M}, 10$ $\mu \mathrm{M}, 25 \mu \mathrm{M}, 50 \mu \mathrm{M}$ or $100 \mu \mathrm{M}$ baicalein for $12 \mathrm{~h}, 24 \mathrm{~h}$ or $48 \mathrm{~h}$ at $37^{\circ} \mathrm{C}$. CCK-8 was added to the cells and incubated 
for $4 \mathrm{~h}$ at $37^{\circ} \mathrm{C}$. The absorbance was read at $450 \mathrm{~nm}$ using a microplate reader (BioRad, CA, USA).

\section{Experimental design}

Serum-starved articular chondrocytes were treated with $10 \mathrm{ng} / \mathrm{ml} \mathrm{IL-1 \beta}$ alone for $0,4,8,12$ and $24 \mathrm{~h}$ or pretreated with $10 \mathrm{ng} / \mathrm{ml} \mathrm{IL-1} \beta$ for $24 \mathrm{~h}$ followed by cotreatment with $10 \mathrm{ng} / \mathrm{ml}$ IL- $1 \beta$ and $50 \mu \mathrm{M}$ baicalein for $0,12,24,36$ and $48 \mathrm{~h}$. The experiments described in the present study were specifically designed to mimic the cellular events that occur in the clinical condition of OA.

For the investigation of $\mathrm{NF}-\kappa \mathrm{B}$ translocation and phosphorylation, serum-starved chondrocyte cultures were treated either with $10 \mathrm{ng} / \mathrm{ml} \mathrm{IL}-1 \beta$ for $0,5,10,20,30,40$, 50 and $60 \mathrm{~min}$ or pretreated with $10 \mathrm{ng} / \mathrm{ml} \mathrm{IL}-1 \beta$ for 0,5 , $10,20,30,40,50$ and $60 \mathrm{~min}$ and then co-treated with 10 $\mathrm{ng} / \mathrm{ml} \mathrm{IL-} \beta$ and $50 \mu \mathrm{M}$ baicalein for $4 \mathrm{~h}$.

\section{Immunofluorescence microscopy}

Serum-starved chondrocytes were either left untreated, treated with $10 \mathrm{ng} / \mathrm{ml}$ IL- $1 \beta$ alone for $30 \mathrm{~min}$ or pretreated with $10 \mathrm{ng} / \mathrm{ml} \mathrm{IL}-1 \beta$ for $30 \mathrm{~min}$ followed by co-treatment with $10 \mathrm{ng} / \mathrm{ml} \mathrm{IL-1 \beta}$ and $50 \mu \mathrm{M}$ baicalein for $2 \mathrm{~h}$. Samples were rinsed three times in phosphate buffered saline (PBS) and then overlaid with protease-free bovine serum albumin (BSA) and $0.3 \%$ Triton-X100 for 60 min at RT, rinsed with PBS and incubated with primary antibodies (phospho-p65, 1:100 in PBS) in a humidified chamber overnight at $4^{\circ} \mathrm{C}$. They were then gently washed three times with PBS before incubation with secondary antibody (goat anti-rabbit immunoglobulin, 1:250 in PBS) for $90 \mathrm{~min}$ at RT. After rinsing with PBS three times, the samples were incubated with DAPI for $10 \mathrm{~min}$ at RT. Cells were washed three times with PBS and then incubated with Phalloidin for $15 \mathrm{~min}$ at RT. Finally, the samples were rinsed three times with PBS before being covered with water-soluble mounting medium and examined under laser confocal fluorescence microscopy.

\section{Western blot analysis}

Total cellular protein, nuclear or cytoplasmic fractions in articular chondrocytes were extracted with cell lysis buffer, and the concentrations were then determined according to the bicinchoninic acid system using BSA as a standard. Equal quantities of total proteins were separated by SDS-PAGE and then transferred onto nitrocellulose filter (NC) membranes. The membrane was blocked with $5 \%(\mathrm{w} / \mathrm{v})$ skimmed milk powder or $3 \%(\mathrm{w} / \mathrm{v})$ BSA at RT for $1 \mathrm{~h}$ and incubated with primary antibodies at $4^{\circ} \mathrm{C}$ overnight. After rinsing three times in Tris-buffered saline (TBS) with 20\% (v/v) Tween 20, the membrane was incubated with the secondary antibody conjugated with horseradish peroxidase at room temperature for $1 \mathrm{~h}$. Finally, the blots were developed with the ECL reagent through Western Blotting Detection System (Amersham Life Science, UK).

\section{Quantitative reverse transcription-PCR (qPCR)}

Total RNA was isolated from different samples using RNAiso Plus according to the manufacturer's instructions. $500 \mathrm{ng}$ of total RNA was reverse-transcribed using the PrimeScript RT reagent kit. The levels of mRNA expression were determined using SYBR Premix Ex Taq. Expression of GAPDH was used as endogenous control. Quantitative realtime PCR data were calculated by the $2^{(-}$ ${ }_{\Delta \Delta C T)}$ method. Primer sequences are listed in Table 1.

\section{Statistical analysis}

All experiments were performed in triplicate. The statistical analysis was performed using GraphPad Prism 7.0 (GraphPad Software Inc., USA) software. One-way analysis of variance (ANOVA) analysis was used for the statistical comparison of multiple groups. Values were expressed as the means \pm standard error of mean (SEM). $P<0.05$ was considered significant.

\section{Authors contribution}

YL and LG designed the study. YL, JW, XL, RJ and GW performed the cell experiments. YL, JW, XF and XL contribute to the immunological experiment. YL, TM, ZZ, HB, and XS collected data for the Cell viability assay and qPCR. YL and JW collected and analyzed data. YL, JW and LG interpreted the data. YL wrote and edited the manuscript. All authors critically reviewed content and approved final version for publication.

\section{ACKNOWLEDGMENTS}

This study was supported by National Key Technology Support Programme of China (2012BAD46B02-03) and National Key Research and Development Plan of China (2017YFD0502202).

\section{CONFLICTS OF INTEREST}

We declare that we do not have any conflict of interest in connection with the work submitted. 


\section{REFERENCES}

1. Scanzello CR, Goldring SR. The role of synovitis in osteoarthritis pathogenesis. Bone. 2012; 51: 249-57. doi: 10.1016/j.bone.2012.02.012.

2. Jansen H, Meffert RH, Birkenfeld F, Petersen W, Pufe T. Detection of vascular endothelial growth factor (VEGF) in moderate osteoarthritis in a rabbit model. Ann Anat. 2012; 194: 452-6. doi: 10.1016/j.aanat.2012.01.006.

3. Hou CH, Tang CH, Hsu CJ, Hou SM, Liu JF. CCN4 induces IL-6 production through alphavbeta5 receptor, PI3K, Akt, and NF-kappaB singling pathway in human synovial fibroblasts. Arthritis Res Ther. 2013; 15: R19. doi: 10.1186/ar4151.

4. Fernandes JC, Martel-Pelletier J, Pelletier JP. The role of cytokines in osteoarthritis pathophysiology. Biorheology. 2002; 39: 237-46.

5. Li HB, Jiang Y, Chen F. Separation methods used for Scutellaria baicalensis active components. J Chromatogr B Analyt Technol Biomed Life Sci. 2004; 812: 277-90. doi: 10.1016/j.jchromb.2004.06.045.

6. Gao Z, Huang K, Yang X, Xu H. Free radical scavenging and antioxidant activities of flavonoids extracted from the radix of Scutellaria baicalensis Georgi. Biochim Biophys Acta. 1999; 1472: 643-50.

7. Wang HK, Xia Y, Yang ZY, Natschke SL, Lee KH. Recent advances in the discovery and development of flavonoids and their analogues as antitumor and anti-HIV agents. Adv Exp Med Biol. 1998; 439: 191-225.

8. Wu JA, Attele AS, Zhang L, Yuan CS. Anti-HIV activity of medicinal herbs: usage and potential development. Am J Chin Med. 2001; 29: 69-81. doi: 10.1142/ S0192415X01000083.

9. Ma SC, Du J, But PP, Deng XL, Zhang YW, Ooi VE, Xu HX, Lee SH, Lee SF. Antiviral Chinese medicinal herbs against respiratory syncytial virus. J Ethnopharmacol. 2002; 79: 205-11.

10. Huang RL, Chen CC, Huang HL, Chang CG, Chen CF, Chang C, Hsieh MT. Anti-hepatitis B virus effects of wogonin isolated from Scutellaria baicalensis. Planta Med. 2000; 66: 694-8. doi: 10.1055/s-2000-9775.

11. Guo Q, Zhao L, You Q, Yang Y, Gu H, Song G, Lu N, Xin J. Anti-hepatitis B virus activity of wogonin in vitro and in vivo. Antiviral Res. 2007; 74: 16-24. doi: 10.1016/j. antiviral.2007.01.002.

12. Kimura Y, Okuda H, Ogita Z. Effects of flavonoids isolated from scutellariae radix on fibrinolytic system induced by trypsin in human umbilical vein endothelial cells. J Nat Prod. 1997; 60: 598-601. doi: 10.1021/np9700351.

13. Huang Y, Tsang SY, Yao X, Chen ZY. Biological properties of baicalein in cardiovascular system. Curr Drug Targets Cardiovasc Haematol Disord. 2005; 5: 177-84.

14. Chi YS, Lim H, Park H, Kim HP. Effects of wogonin, a plant flavone from Scutellaria radix, on skin inflammation: in vivo regulation of inflammation-associated gene expression. Biochem Pharmacol. 2003; 66: 1271-8.

15. Wang CZ, Mehendale SR, Yuan CS. Commonly used antioxidant botanicals: Active constituents and their potential role in cardiovascular illness. Am J Chin Med. 2007; 35: 543-58. doi: 10.1142/S0192415x07005053.

16. Yano H, Mizoguchi A, Fukuda K, Haramaki M, Ogasawara S, Momosaki S, Kojiro M. The herbal medicine sho-saikoto inhibits proliferation of cancer cell lines by inducing apoptosis and arrest at the G0/G1 phase. Cancer Res. 1994; 54: 448-54.

17. Motoo Y, Sawabu N. Antitumor effects of saikosaponins, baicalin and baicalein on human hepatoma cell lines. Cancer Lett. 1994; 86: 91-5.

18. Ikemoto S, Sugimura K, Yoshida N, Yasumoto R, Wada $\mathrm{S}$, Yamamoto K, Kishimoto T. Antitumor effects of Scutellariae radix and its components baicalein, baicalin, and wogonin on bladder cancer cell lines. Urology. 2000; 55: 951-5.

19. Zhang DY, Wu J, Ye F, Xue L, Jiang S, Yi J, Zhang W, Wei H, Sung M, Wang W, Li X. Inhibition of cancer cell proliferation and prostaglandin E2 synthesis by Scutellaria baicalensis. Cancer Res. 2003; 63: 4037-43.

20. Yu J, Liu H, Lei J, Tan W, Hu X, Zou G. Antitumor activity of chloroform fraction of Scutellaria barbata and its active constituents. Phytother Res. 2007; 21: 817-22. doi: 10.1002/ ptr.2062.

21. Ma Z, Otsuyama K, Liu S, Abroun S, Ishikawa H, Tsuyama N, Obata M, Li FJ, Zheng X, Maki Y, Miyamoto K, Kawano MM. Baicalein, a component of Scutellaria radix from Huang-Lian-Jie-Du-Tang (HLJDT), leads to suppression of proliferation and induction of apoptosis in human myeloma cells. Blood. 2005; 105: 3312-8. doi: 10.1182/blood-2004-10-3915.

22. Nakano H, Nakajima A, Sakon-Komazawa S, Piao JH, Xue $\mathrm{X}$, Okumura K. Reactive oxygen species mediate crosstalk between NF-kappaB and JNK. Cell Death Differ. 2006; 13: 730-7. doi: 10.1038/sj.cdd.4401830.

23. Chen K, Zhang S, Ji Y, Li J, An P, Ren H, Liang R, Yang $\mathrm{J}, \mathrm{Li} \mathrm{Z}$. Baicalein inhibits the invasion and metastatic capabilities of hepatocellular carcinoma cells via downregulation of the ERK pathway. PLoS One. 2013; 8: e72927. doi: 10.1371/journal.pone.0072927.

24. Musumeci G, Aiello FC, Szychlinska MA, Di Rosa M, Castrogiovanni P, Mobasheri A. Osteoarthritis in the XXIst Century: Risk Factors and Behaviours that Influence Disease Onset and Progression. Int J Mol Sci. 2015; 16: 6093-112. doi: 10.3390/ijms16036093.

25. Musumeci G, Loreto C, Carnazza ML, Martinez G. Characterization of apoptosis in articular cartilage derived from the knee joints of patients with osteoarthritis. Knee Surg Sports Traumatol Arthrosc. 2011; 19: 307-13. doi: 10.1007/s00167-010-1215-0.

26. Musumeci G, Loreto C, Carnazza ML, Strehin I, Elisseeff 
J. OA cartilage derived chondrocytes encapsulated in poly(ethylene glycol) diacrylate (PEGDA) for the evaluation of cartilage restoration and apoptosis in an in vitro model. Histol Histopathol. 2011; 26: 1265-78.

27. Aggarwal BB. Nuclear factor- $\kappa \mathrm{B}$ : The enemy within. Cancer Cell. 2004; 6: 203-8.

28. Aggarwal BB, Takada Y. Pro-apototic and anti-apoptotic effects of tumor necrosis factor in tumor cells. Role of nuclear transcription factor NF-kappaB. Cancer Treat Res. 2005; 126: 103-27.

29. Largo R, Alvarez-Soria MA, Díez-Ortego I, Calvo E, Sánchez-Pernaute $\mathrm{O}$, Egido J, Herrero-Beaumont G. Glucosamine inhibits IL-1beta-induced NFkappaB activation in human osteoarthritic chondrocytes. Osteoarthritis Cartilage. 2003; 11:290-98.

30. Lu S, Xiao X, Cheng M. Matrine inhibits IL-1beta-induced expression of matrix metalloproteinases by suppressing the activation of MAPK and NF-kappaB in human chondrocytes in vitro. Int J Clin Exp Pathol. 2015; 8: 476472.

31. de Crombrugghe B, Lefebvre V, Behringer RR, Bi W, Murakami S, Huang W. Transcriptional mechanisms of chondrocyte differentiation. Matrix Biol. 2000; 19: 389-94.

32. Sizemore N, Lerner N, Dombrowski N, Sakurai H, Stark GR. Distinct roles of the Ikappa B kinase alpha and beta subunits in liberating nuclear factor kappa B (NF-kappa B) from Ikappa B and in phosphorylating the p65 subunit of NF-kappa B. J Biol Chem. 2002; 277: 3863-9. doi: 10.1074/ jbc.M110572200.

33. Kumar A, Takada Y, Boriek AM, Aggarwal BB. Nuclear factor-kappaB: its role in health and disease. J Mol Med (Berl). 2004; 82: 434-48. doi: 10.1007/s00109-004-0555-y.

34. Wei ZF, Wang XQ, Peng X, Wang W, Zhao CJ, Zu YG, $\mathrm{Fu}$ YJ. Fast and green extraction and separation of main bioactive flavonoids from Radix Scutellariae. Ind Crops Prod. 2015; 63: 175-81. doi: 10.1016/j.indcrop.2014.10.013.

35. Mu X, He G, Cheng Y, Li X, Xu B, Du G. Baicalein exerts neuroprotective effects in 6-hydroxydopamine-induced experimental parkinsonism in vivo and in vitro. Pharmacol Biochem Behav. 2009; 92:642-48.

36. Zhang S, Ye J, Dong G. Neuroprotective effect of baicalein on hydrogen peroxide-mediated oxidative stress and mitochondrial dysfunction in PC12 cells. J Mol Neurosci. 2010; 40:311-20.

37. Lee HJ, Noh YH, Lee DY, Kim YS, Kim KY, Chung YH, Lee WB, Kim SS. Baicalein attenuates 6-hydroxydopamineinduced neurotoxicity in SH-SY5Y cells. Eur J Cell Biol. 2005; 84: 897-905. doi: 10.1016/j.ejcb.2005.07.003.

38. Culver C, Sundqvist A, Mudie S, Melvin A, Xirodimas D, Rocha S. Mechanism of hypoxia-induced NF-kappaB. Mol Cell Biol. 2010; 30: 4901-21. doi: 10.1128/MCB.00409-10.

39. Glasgow JN, Qiu J, Rassin D, Grafe M, Wood T, Perez-Pol JR. Transcriptional regulation of the BCL-X gene by NFkappaB is an element of hypoxic responses in the rat brain.
Neurochem Res. 2001; 26:647-59.

40. Sarnico I, Lanzillotta A, Boroni F, Benarese M, Alghisi M, Schwaninger M, Inta I, Battistin L, Spano P, Pizzi M. NF-kappaB p50/RelA and c-Rel-containing dimers: opposite regulators of neuron vulnerability to ischaemia. J Neurochem. 2009; 108: 475-85. doi: 10.1111/j.14714159.2008.05783.x.

41. Heinegard D, Saxne T. The role of the cartilage matrix in osteoarthritis. Nat Rev Rheumatol. 2011; 7: 50-6. doi: 10.1038/nrrheum.2010.198.

42. Goldring MB, Otero M, Plumb DA, Dragomir C, Favero M, El Hachem K, Hashimoto K, Roach HI, Olivotto E, Borzì RM, Marcu KB. Roles of inflammatory and anabolic cytokines in cartilage metabolism: signals and multiple effectors converge upon MMP-13 regulation in osteoarthritis. Eur Cell Mater. 2011; 21:202-20.

43. Sellam J, Berenbaum F. The role of synovitis in pathophysiology and clinical symptoms of osteoarthritis. Nat Rev Rheumatol. 2010; 6: 625-35. doi: 10.1038/ nrrheum.2010.159.

44. Troeberg L, Nagase H. Proteases involved in cartilage matrix degradation in osteoarthritis. Biochim Biophys Acta. 2012; 1824: 133-45. doi: 10.1016/j.bbapap.2011.06.020.

45. Smith GN Jr. The role of collagenolytic matrix metalloproteinases in the loss of articular cartilage in osteoarthritis. Front Biosci. 2006; 11:3081-95.

46. Chubinskaya S, Kuettner KE, Cole AA. Expression of matrix metalloproteinases in normal and damaged articular cartilage from human knee and ankle joints. Lab Invest. 1999; 79: 1669-77.

47. Eguchi T, Kubota S, Kawata K, Mukudai Y, Uehara J, Ohgawara T, Ibaragi S, Sasaki A, Kuboki T, Takigawa M. Novel Transcription Factor-Like Function of Human Matrix Metalloproteinase 3 Regulating the CTGF/CCN2 Gene. Mol Cell Biol. 2008; 28: 2391-413.

48. Chikanza I, Fernandes L. Novel strategies for the treatment of osteoarthritis. Expert Opin Investig Drugs. 2000; 9: 1499-510. doi: 10.1517/13543784.9.7.1499.

49. Sakai T, Kambe F, Mitsuyama H, Ishiguro N, Kurokouchi $\mathrm{K}$, Takigawa M, Iwata H, Seo H. Tumor necrosis factor $\alpha$ induces expression of genes for matrix degradation in human chondrocyte-like HCS-2/8 cells through activation of NF- $\kappa \mathrm{B}$ : Abrogation of the tumor necrosis factor $\alpha$ effect by proteasome inhibitors. J Bone Miner Res. 2001; 16: 1272-80.

50. Barnes PJ, Karin M. Nuclear factor-kappaB: a pivotal transcription factor in chronic inflammatory diseases. N Engl J Med. 1997; 336: 1066-71. doi: 10.1056/ NEJM199704103361506.

51. Amin AR, Dave M, Attur M, Abramson SB. COX-2, NO, and cartilage damage and repair. Curr Rheumatol Rep. 2000; 2: 447-53.

52. Nedelec E, Abid A, Cipolletta C, Presle N, Terlain B, Netter $\mathrm{P}$, Jouzeau J. Stimulation of cyclooxygenase-2-activity 
by nitric oxide-derived species in rat chondrocyte: lack of contribution to loss of cartilage anabolism. Biochem Pharmacol. 2001; 61: 965-78.

53. Marcu KB, Otero M, Olivotto E, Borzi RM, Goldring MB. NF-kappaB signaling: multiple angles to target OA. Curr Drug Targets. 2010; 11: 599-613.

54. Miagkov AV, Kovalenko DV, Brown CE, Didsbury JR, Cogswell JP, Stimpson SA, Baldwin AS, Makarov SS. $N F-\kappa B$ activation provides the potential link between inflammation and hyperplasia in the arthritic joint. Proc Natl Acad Sci USA. 1998; 95: 13859-64.

55. Gilmore TD. Introduction to NF-kappaB: players, pathways, perspectives. Oncogene. 2006; 25: 6680-4. doi: 10.1038/ sj.onc. 1209954.

56. Perkins ND. The diverse and complex roles of NF-kappaB subunits in cancer. Nat Rev Cancer. 2012; 12: 121-32. doi: $10.1038 / \mathrm{nrc} 3204$

57. Bi W, Deng JM, Zhang Z, Behringer RR, de Crombrugghe B. Sox 9 is required for cartilage formation. Nat Genet. 1999; 22:85-89.

58. Bi W, Huang W, Whitworth DJ, Deng JM, Zhang Z, Behringer RR, de Crombrugghe B. Haploinsufficiency of Sox9 results in defective cartilage primordia and premature skeletal mineralization. Proc Natl Acad Sci U S A. 2001; 98: 6698-703. doi: 10.1073/pnas.111092198.

59. Akiyama H, Chaboissier MC, Martin JF, Schedl A, de Crombrugghe B. The transcription factor Sox9 has essential roles in successive steps of the chondrocyte differentiation pathway and is required for expression of Sox 5 and Sox6. Genes Dev. 2002; 16:2813-28.
60. Brew CJ, Clegg PD, Boot-Handford RP, Andrew JG, Hardingham T. Gene expression in human chondrocytes in late osteoarthritis is changed in both fibrillated and intact cartilage without evidence of generalised chondrocyte hypertrophy. Ann Rheum Dis. 2010; 69: 234-40. doi: 10.1136/ard.2008.097139.

61. Sherwood J, Bertrand J, Nalesso G, Poulet B, Pitsillides A, Brandolini L, Karystinou A, De Bari C, Luyten FP, Pitzalis C, Pap T, Dell'Accio F. A homeostatic function of CXCR2 signalling in articular cartilage. Ann Rheum Dis. 2015; 74 : 2207-15. doi: 10.1136/annrheumdis-2014-205546.

62. Ikegami D, Akiyama H, Suzuki A, Nakamura T, Nakano T, Yoshikawa H, Tsumaki N. Sox9 sustains chondrocyte survival and hypertrophy in part through Pik3ca-Akt pathways. Development. 2011; 138: 1507-19. doi: 10.1242/ dev.057802.

63. Dy P, Wang W, Bhattaram P, Wang Q, Wang L, Ballock RT, Lefebvre V. Sox9 directs hypertrophic maturation and blocks osteoblast differentiation of growth plate chondrocytes. Dev Cell. 2012; 22:597-609.

64. Leung VY, Gao B, Leung KK, Melhado IG, Wynn SL, Au TY, Dung NW, Lau JY, Mak AC, Chan D, Cheah KS. SOX9 governs differentiation stage-specific gene expression in growth plate chondrocytes via direct concomitant transactivation and repression. PLoS Genet. 2011; 7:e1002356.

65. Shakibaei M, John T, De Souza P, Rahmanzadeh R, Merker HJ. Signal transduction by betal integrin receptors in human chondrocytes in vitro: collaboration with the insulinlike growth factor-I receptor. Biochem J. 1999; 342:615-23. 